\title{
Entrepreneurship, job creation and wage growth
}

Malchow-Møller, Nikolaj; Schjerning, Bertel; Sørensen, Anders

Published in:

Small Business Economics

DOI:

10.1007/s11187-009-9173-y

Publication date:

2011

Document version

Publisher's PDF, also known as Version of record

Citation for published version (APA):

Malchow-Møller, N., Schjerning, B., \& Sørensen, A. (2011). Entrepreneurship, job creation and wage growth.

Small Business Economics, 36(1), 15-32. https://doi.org/10.1007/s11187-009-9173-y 


\section{CAM}

Centre for Applied

Microeconometrics

Department of Economics

University of Copenhagen

http://www.econ.ku.dk/CAM/

Working paper no. 2009-01

Entrepreneurship, Job Creation, and Wage Growth

Nikolaj Malchow-Møller, Bertel Schjerning and Anders Sørensen 


\title{
Entrepreneurship, Job Creation, and Wage Growth ${ }^{*}$
}

\author{
By: \\ Nikolaj Malchow-Møller, Centre for Economic and Business Research (CEBR) and \\ University of Southern Denmark \\ Bertel Schjerning, University of Copenhagen and Centre for Applied \\ Microeconometrics (CAM) \\ Anders Sørensen, Copenhagen Business School and Centre for Economic and \\ Business Research (CEBR)
}

\begin{abstract}
This paper analyses the importance of entrepreneurs for job creation and wage growth. Relying on unique data that cover all establishments, firms and individuals in the Danish private sector, we are able to distil a number of different subsets from the total set of new establishments - subsets which allow us to more precisely capture the "truly new" or "entrepreneurial" establishments than in previous studies. Using these data, we find that while new establishments in general account for one third of the gross job creation in the economy, entrepreneurial establishments are responsible for around $25 \%$ of this, and thus only account for about $8 \%$ of total gross job creation in the economy. However, entrepreneurial establishments seem to generate more additional jobs than other new establishments in the years following entry. Finally, the jobs generated by entrepreneurial establishments are to a large extent low-wage jobs, as they are not found to contribute to the growth in average wages.
\end{abstract}

Keywords: Job creation, entrepreneurial establishments, wage growth JEL: L26, J21, J31

\footnotetext{
* Acknowledgements: We thank the National Agency for Enterprise and Housing for financial support for this project. Sørensen also gratefully acknowledges financial support from Tuborgfondet. The usual disclaimer applies. Malchow-Møller: Centre for Economic and Business Research (CEBR), and School of Business and Economics, University of Southern Denmark, Porcelænshaven 16A, 2000 Frederiksberg, Denmark; nmm.cebr@cbs.dk. Schjerning: University of Copenhagen and Centre for Applied Microeconometrics (CAM), Bispetorvet 1-3, DK-1455 Copenhagen K., Denmark; bertel.schjerning@econ.ku.dk. Sørensen: Department of Economics, Copenhagen Business School and Centre for Economic and Business Research (CEBR), Porcelænshaven 16A, 2000 Frederiksberg, Denmark; as.eco@cbs.dk.
} 


\section{Introduction}

This paper analyses the importance of entrepreneurs for job creation and wage growth in the Danish private sector. Using a unique data set that combines information about establishments with information about firm formation and ownership, we can distil a number of different subsets from the total set of new establishments - subsets which enable us to more precisely capture the "truly new" or "entrepreneurial" establishments than in previous studies. This in turn allows us to provide detailed measures of job creation by entrepreneurial establishments as well as their contribution to average wage growth.

Entrepreneurs are widely believed to play an important role for job creation and wage growth. Schumpeter originally used the term "creative destruction" to describe the process by which new and more productive firms - the entrepreneurs - replace old and less productive firms in the economy.

There has been substantial empirical work on the importance of small businesses in job creation; see, e.g., Birch (1979, 1987); Davis et al. (1996a, 1996b); and Neumark et al. (2008). The main impression from these studies is that small firms play an important role in job creation. Birch (1987) thus found that firms with less than 20 employees account for $88 \%$ of overall US employment growth. Davis et al. (1996a, 1996b) later argued that Birch's findings had an upward bias in the contribution from small firms. Presenting a method without this problem, Davis et al. (1996b) found that establishments with an average size of less than 100 employees accounted for about one third of gross job creation in US manufacturing over the period 1973-1988. Using the method developed by Davis et al., Neumark et al. (2008) studied the overall economy and found that establishments with an average size of less than 100 employees accounted for $70 \%$ of gross job creation in the period 1992-2002, while establishments with less than 20 employees in themselves accounted for almost $50 \%$.

While the importance of small businesses is thus well documented - and is often taken as evidence of the importance of entrepreneurs in job creation (see, e.g., Parker, 2004) - the role of new businesses in job creation has received much less attention. This has to do with the difficulties involved in identifying the "truly new" firms. Several studies have thus analysed the role of new establishments in job creation; see, e.g., Dunne et al. (1989); Davis and Haltiwanger (1992); Davis et al. (1996a); Klette and Mathiassen (1996); Spletzer (2000) and Neumark et al. (2006). New establishments, however, may belong to existing firms and do therefore not represent entrepreneurial job creation in the Schumpeterian sense of the word.

To our knowledge, the only other study that distinguishes new establishments belonging to new firms from new establishments belonging to existing firms is Neumark et al. (2006). They find that births of new firms are particularly important in job creation. Specifically, new establishments account for $60-70 \%$ of gross job creation of which $2 / 3$ is due to new firms. This implies that at least $40 \%$ of total gross job creation is accounted for by the birth of new firms. ${ }^{1}$

\footnotetext{
${ }^{1}$ At a more aggregate level, Audretsch and Fritsch (2002) and van Stel and Storey (2004) consider the relationship between start-up rates and employment changes across regions.
} 
We shall argue that firms that are formally new need not be entrepreneurial. ${ }^{2}$ An important objective of the present paper is therefore to identify alternative subsets of the new establishments that can more appropriately be characterised as entrepreneurial. This includes new establishments by new self-employed and new establishments by "truly new" firms. To the best of our knowledge, no study has previously analysed job creation by such new entrepreneurial establishments. Furthermore, the different subsets of new establishments allow us to compare the "business birth" approach and the "self-employment" approach to measuring entrepreneurs.

We also address the quality of jobs created by entrepreneurial establishments by analysing the contribution to average wage growth. In addition to evaluating the aggregate effect of new establishments on the wage level, we are also able to separate out the relative importance of the entrepreneurial establishments.

Related to this, Brixy, Kohaut and Schnabel (2007) have recently found that wages in newly founded establishments are 8 percent lower than in other establishments of similar size. Their study is based on a sample of around 800 newly founded firms in Germany. Moreover, Brown and Medoff (2003) have previously found that firms that have been in business for a long time pay higher wages. However, when controlling for worker characteristics, the difference is not significant. Wages are found to fall in the beginning of a firm's life and increase later. As for job creation, there is also a large literature considering the relationship with firm size. Here, it is generally found that small firms pay lower wages than large firms; see, e.g., Oi and Idson (1999).

Our study relies on a unique register dataset that covers the entire Danish private sector. It allows us to match all individuals with establishments, and all establishments with firms (the legal unit). Thus, firm level information about firm age and number of establishments can be used at the establishment level together with individual information on the owners of personally-owned firms (the self-employed). This implies that we can identify the total set of new establishments, as well as different subsets of these, which better capture the entrepreneurial establishments.

Taking a "business birth" approach to entrepreneurship, we can identify the entrepreneurial establishments from the age of the firm to which they belong. However, many firms that are formally new may in practice be little more than a renaming of the company or the result of organising existing or additional activities in different legal entities. To deal with this problem, Statistics Denmark has identified the subset of new firms which is considered as the "truly new" firms. A truly new firm is a firm that has been registered for VAT and has never been run (i) by another owner; (ii) under another form of ownership; (iii) under another firm; or (iv) by a personal owner who already runs other personally-owned firms. Using this information, we are able to get an improved measure of the entrepreneurial establishments. On the other hand, this approach may not capture all relevant firms owned by self-employed individuals.

Alternatively, taking a "self-employment" approach to entrepreneurship, we can identify the entrepreneurial establishments from the newly self-employed individuals. Apart from giving us a measure of the contribution of new self-employed to job creation - which is interesting in its own right given the large (political and academic) interest in the self-employed - this approach has the advantage of including new establishments belonging to personally-owned firms that were founded formally several years ago, but only became active (in terms of employment) at a later stage.

\footnotetext{
${ }^{2}$ See also Storey (1991) for an earlier discussion of the problems in identifying the "wholly new firms" among the set of new or entrant firms.
} 
Combining the different subsets of new establishments enable us to construct a new measure that more precisely captures the "entrepreneurial" establishments than in previous studies. We choose this measure as the union between new establishments belonging to "truly new" firms and new establishments belonging to new self-employed.

Equipped with this measure and the different subsets, we analyse the importance of entrepreneurship in gross job creation using the method developed by Davis and Haltiwanger (1992), and Davis et al. (1996a). As also the "quality" of the jobs created is of interest, we subsequently assess the impact from entrepreneurship on the average wage level using a decomposition method from Foster et al. (2001).

We find that new establishments account for around one third of overall gross job creation even though they only account for $4-5 \%$ of total employment. While half of these jobs are generated by new establishments of new firms, using our measure of entrepreneurial establishments, we find that these account for about $25 \%$ of the gross job creation by new establishments. Thus, entrepreneurs are responsible for around $8 \%$ of total gross job creation in the economy.

Even though jobs created by entrepreneurial establishments do not exhibit higher persistence than jobs created by other new establishments, we find some evidence that entrepreneurial establishments create more additional jobs within the establishment in the years following entry. Quantitatively, this may raise the contribution of entrepreneurs in total job creation by a few percentage points.

We also analyse the "quality" of jobs generated by entrepreneurship by decomposing the change in average wages into the contributions from continuing, exiting and entering establishments. While exiting establishments contribute significantly to wage growth - confirming Schumpeter's idea of the destruction of less productive firms - the effects of new establishments are less clear. In general, these are found to account for between -10 and 10 percent of the increase in the average wage. Among these establishments, establishments of new self-employed have a strong negative contribution, while the establishments of truly new firms are found neither to increase nor to decrease average wages. Thus, it seems fair to conclude that entrepreneurs generate low-wage jobs on average.

The rest of the paper is organised as follows. In Section 2, we describe the data and present the different subsets of new establishments in detail. In Section 3, we analyse job creation focusing on the contribution to this process by the entrepreneurial establishments. The contribution of entrepreneurial establishments to the growth in the average wage is analysed in Section 4. Finally, Section 5 concludes.

\section{Data and Definitions}

This study draws on data from a number of Danish registers administered by Statistics Denmark. The registers cover the entire population of individuals, establishments and firms in the Danish economy. 
First, we use data from the Integrated Database for Labour Market Research (IDA). IDA contains detailed annual register-based data on all establishments and all individuals in Denmark. For example, for each establishment, the number of employees, the total wage bill, and the industry classification are observed. With respect to the present study, the IDA database has three important characteristics. (i) It covers the entire population of establishments and individuals. (ii) It is longitudinal making it possible to track individuals and establishments from year to year. Thus, there is only natural attrition in the data set, i.e., births, deaths and migration of individuals, and start-ups and closures of establishments. The panel currently covers the period 1980-2005, and the occupational status of each individual is observed once a year (the last week of November). (iii) Workers are linked to establishments, making it possible to identify all the employees of any establishment in each year, as well as the owners of establishments in personally-owned firms.

Second, establishments in IDA can be linked to firms (the legal units) for the period 1995-2002. In this way, we can assign firm level information to each establishment in the firm, including the age (registration date) of the firm from the Enterprise Statistics. Furthermore, this link allows us to obtain information about other establishments within the same firm.

Third, we combine the information above with a special database on "truly new" firms, which has been developed by Statistics Denmark. In this database, all new firm registrations in the years 19932002 have been collected and subsequently been merged with additional information to eliminate registrations which do not reflect "truly new" firms (more about this below). This additional firm information can be merged onto the Enterprise Statistics and used at the establishment level.

\subsection{Establishments}

Our population of interest is the set of establishments in the Danish private sector in the years 19942003. However, we exclude the primary sector as well as industries not subject to value-added taxes (VAT) such as the financial and educational sectors as the database on truly new firms does not cover these industries. ${ }^{3}$

The longitudinal identity of an establishment is well defined in IDA. An establishment is thus considered as continuing from one year to the next if (at least) one of the following criteria is fulfilled in two consecutive years: (i) same owner and same industry; (ii) same owner and same employees; (iii) same employees and same address; or (iv) same employees and same industry. ${ }^{4}$ Hence, even in cases where the establishment changes location or is taken over by a new owner, the establishment is still considered as a continuing establishment, thereby reducing the possibility of spuriously recording an establishment death followed by an establishment start-up.

Given the well-defined longitudinal identity of establishments, they provide the most reliable basis for measuring the amount of jobs created and destructed in the economy. Thus, the measures of job creation, job destruction and average wages used in this paper are all constructed at the establishment level. Finally, note that there must be employees for an establishment to figure as an establishment in the data set. A self-employed individual without employees is therefore not considered as having an establishment.

\footnotetext{
${ }^{3}$ Note that we exclude all establishments that belong to these industries in at least one year.

${ }^{4}$ By "same employees" is meant that at least $30 \%$ of the employees should be present in both years.
} 


\subsection{Entrepreneurial Establishments}

The simplest way of measuring entrepreneurial job creation is to use total job creation by all new establishments. However, this is likely to "exaggerate" the entrepreneurial activity. Thus, we use various approaches to distil different subsets of new establishments from the total set of new establishments. These are eventually combined into our preferred measure of entrepreneurial establishments.

Several definitions of entrepreneurship are available from the literature. Often, entrepreneurs are simply measured as the number of self-employed or, perhaps more precisely, as the number of new self-employed; see Iversen et al. (2008). According to such a measure, the entrepreneurial establishments would be those set up and owned by newly self-employed individuals. This measure, however, leaves out those entrepreneurs who form incorporated businesses as these individuals are not technically self-employed according to the registers, but instead employees of their incorporated businesses. Only the owners of personally-owned firms are registered as self-employed.

An alternative measure of entrepreneurship therefore takes a firm perspective, focusing on all new firms (the legal unit) - both incorporated and non-incorporated (personally-owned) in a given year. However, all firms which are new in a legal sense need not be new in any practical sense. Instead, they may, e.g., reflect that existing or new activities are organised in new legal units for legal and/or tax reasons. As such, the establishments of these firms are not necessarily "entrepreneurial". Furthermore, firms that are new in a practical sense, i.e., entrepreneurial, in a given year may have been legally established many years earlier.

Thus, to provide the most comprehensive picture, we develop four different subsets of the new establishments. The first two subsets take an individual perspective focusing on establishments of self-employed individuals, while the latter two take a firm perspective. From these four subsets of new establishments, we can define combinations that better proxy the set of entrepreneurial establishments. We shall return to that below. Figure 1 below illustrates the relationship between the four different subsets and the total set of new establishments.

The first subset of new establishments is defined as the set of new establishments which are owned by newly self-employed individuals. We shall refer to these as "NSE establishments". To be precise, an NSE establishment is a new establishment owned by a self-employed individual who was not self-employed (as his or her primary occupation) the year before. In other words, he or she was either wage employed, unemployed or non-employed in her primary occupation the year before.

The second subset of new establishments is defined as the set of new establishments owned and operated by new employers. This measure is an extension of our first measure, as it also includes new establishments owned by individuals who were self-employed without employees the year before. By construction, the set of NSE establishments thus becomes a perfect subset of this latter set of establishments, which we shall refer to as the set of "NE establishments". See Figure 1 below.

To illustrate the difference between the two measures, consider the self-employed individual who has been running a small handicraft shop on his own for a number of years. If she - after 10 years decides to hire an assistant, she will be setting up a new establishment, and this establishment will then be included in the set of NE establishments in that year. However, as the owner was also selfemployed the year before, the establishment will not be included in the set of NSE establishments. 
The third subset is simply the set of new establishments set up by new firms, i.e., firms which are new in a legal sense. This subset is referred to as the "NF establishments". From the Enterprise Statistics, we know the starting (registration) date of each firm, which allows us to identify among the new establishments those that also belong to new firms. ${ }^{5}$ To operationalise this definition, we define NF establishments as new establishments belonging to firms founded either the same year or the year before. Thus, the new establishment belonging to the small handicraft shop from the example above will not be included in this measure.

A potential critique of this third definition is that many firms that are new in a legal sense are not new in any practical or economic sense. They may instead be the results of restructures, take-overs etc. Statistics Denmark has therefore identified the subset of new firms, which is considered as the "truly new" firms. This provides us with our fourth subset of new establishments, which we shall call the set of "TNF establishments".

Specifically, there are around 35,000-40,000 new firm registrations for VAT each year in Denmark (Statistics Denmark, 2002). From this population, the following new registrations are eliminated: registrations due to take-overs or reorganisations (e.g., from personally-owned to incorporated firms), re-starters, and administrative registrations where firms register existing activities in a new legal entity. This leaves around 15,000-20,000 truly new firms each year (Statistics Denmark, 2002).

A truly new firm is thus a firm that has been registered for VAT in a given year, and has never been run (i) by another owner; (ii) under another form of ownership; (iii) under another firm; or (iv) by a personal owner who already runs other personally-owned firms (Statistics Denmark, 2002). Our TNF establishments are therefore the subset of NF establishments where the firm behind the establishment is not only a new firm but can also be found in this database of truly new firms.

Thus, we may perfectly well have new establishments that meet the conditions for being NSE and NE establishments, but not those for being NF and TNF establishments, and the other way around. For example, consider an individual who has been part-time self-employed for some years and then decides to become full-time self-employed and hires employees. This establishment will be included in the sets of NE and NSE establishments, but not in the sets of NF and TNF establishments as no new legal entity has been established. Similarly, new establishments belonging to (truly) new incorporated firms, and hence are included in the sets of NF and TNF establishments, do not figure among the establishments of the new self-employed (NSE establishments) or the establishments of new employers (NE establishments).

Based on the four subsets of new establishments, we can define our preferred measure of entrepreneurial establishments. The NE and NSE establishments are interesting in their own right as much of the literature has focussed on the self-employed. However, as a measure of entrepreneurial establishments, the NSE measure is to be preferred as the NE establishments may belong to individuals who have been self-employed their entire life just without employees. On the other hand, if one can argue that a self-employed individual only becomes an entrepreneur when (s)he starts to hire employees, the NE establishments would be the preferred measure.

\footnotetext{
${ }^{5}$ van Stel and Storey (2004) have previously used new registrations for VAT as a measure of firm births.
} 
The main problem in using the definitions based on the self-employed is that it leaves out all the incorporated firms, which are likely to be the bigger firms and hence the more important ones in terms of job creation. This takes us to the firm-based definitions.

While the NF establishments provide a far too optimistic picture of entrepreneurial activity, a TNF establishment is much closer to what we would consider to be an entrepreneurial establishment. These are establishments of generically new firms. The only drawback is that this measure leaves out firms which were formally established several years prior to becoming active in terms of employment.

Thus, our preferred measure of entrepreneurial establishments is the union of TNF establishments and NSE establishments. This set (TNFUNSE) includes the new establishments of truly new firms (from a legal perspective) as well as the new establishments of newly self-employed individuals where the legal entity was established at an earlier date. In the remainder of the paper, we shall therefore refer to TNF $\cup$ NSE as the set of entrepreneurial establishments, while we use NE, NSE, $\mathrm{NF}$, and TNF to refer to the different subsets of new establishments defined above.

\subsection{Descriptive Statistics}

The four different subsets of new establishments (NSE, NE, NF, and TNF establishments) and the relationship between these are illustrated in Figure 1 below. The figure also shows the number of establishments in each category in 2001.

Out of 17,186 new establishments in 2001, 4,767 belonged to new employers (NE establishments). These are establishments in personally-owned firms where the owner did not have employees the year before. In approximately half of the cases - 2,576 to be precise - the owner was not even selfemployed the year before. These are the NSE establishments. In other words, approximately half of the new establishments set up by new employers are operated by individuals who were already running their own business the year before; just without employees.

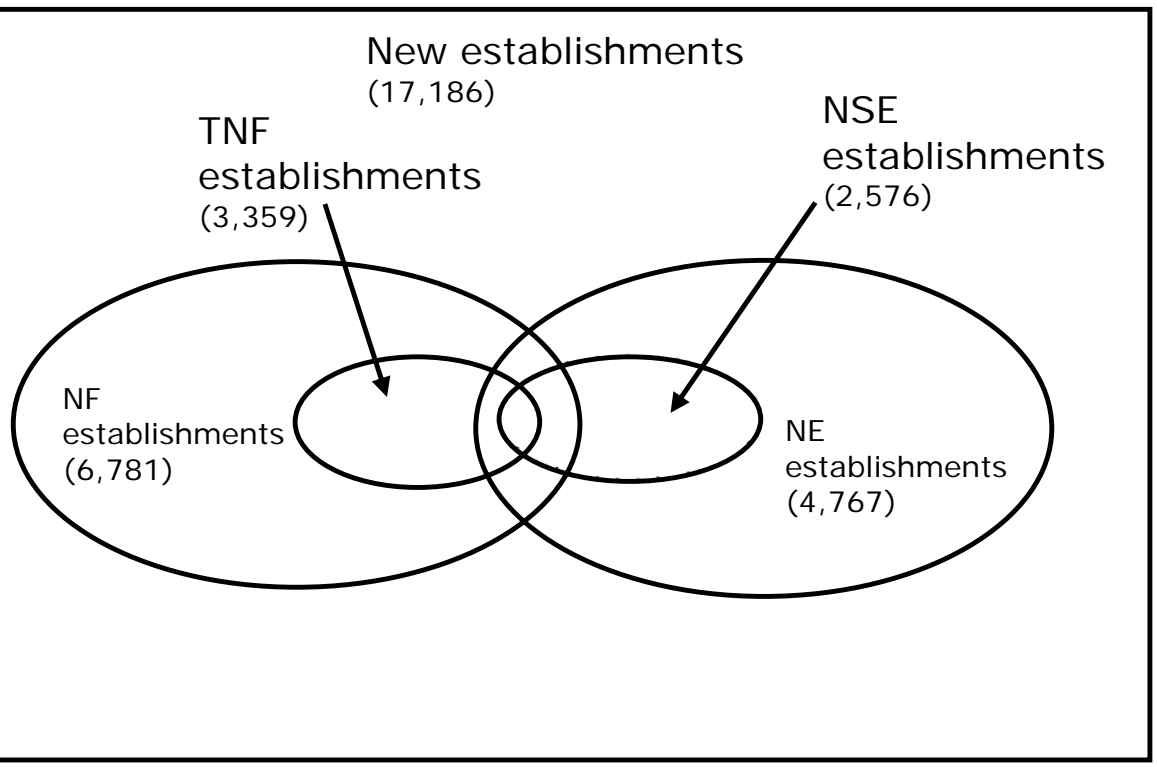

Figure 1: The four subsets of new establishments and the number of establishments in each subset in 2001. 
Turning to the firm-based definitions, we can see that 6,781 of the new establishments were set up by new legal entities, i.e., firms founded within the same or the previous year. These are the NF establishments. In approximately half of the cases $(3,359)$, the firm was also considered a truly new firm. This provides a first illustration of the danger in setting new firms equal to entrepreneurial firms.

Table 1 below contains the number of establishments according to each of the four subsets as well as various combinations of these for the years 1994-2003. Note that the NF establishments and TNF establishments, which are based on the Enterprise Statistics, can only be identified for the years 1996-2001. The table confirms the picture from Figure 1. Roughly speaking, the number of NF establishments is twice as large as the number of TNF establishments. Similarly, the number of NE establishments is twice as high as the number of NSE establishments.

The sizes of the four subsets of new establishments imply that the number of entrepreneurial establishments is significantly smaller that the total number of new establishments. According to table, the union of TNF and NSE establishments thus yields around 4,000-5,000 entrepreneurial establishments each year out of a total of 16,000-18,000 new establishments.

Table 1: New Establishments, 1994-2003

\begin{tabular}{|c|c|c|c|c|c|c|c|c|c|}
\hline & $\begin{array}{c}\text { New } \\
\text { Establishments }\end{array}$ & $\begin{array}{c}\text { NE } \\
\text { Establishments }\end{array}$ & $\begin{array}{c}\text { NSE } \\
\text { Establishments }\end{array}$ & $\begin{array}{c}\text { NF } \\
\text { Establishments }\end{array}$ & $\begin{array}{c}\text { TNF } \\
\text { Establishments }\end{array}$ & $\begin{array}{c}\text { NF } \cup N E \\
\text { Establishments }\end{array}$ & $\begin{array}{c}\text { TNF } \cup \text { NE } \\
\text { Establishments }\end{array}$ & $\begin{array}{c}\text { TNF } \cup N S E \\
\text { Establishments }\end{array}$ & $\begin{array}{l}\text { TNF NSE } \\
\text { Establishments }\end{array}$ \\
\hline Year & \multicolumn{9}{|c|}{ Number of establishments } \\
\hline 1994 & 17.937 & 5.754 & 2.840 & - & - & - & - & - & - \\
\hline 1995 & 16.926 & 5.986 & 3.105 & - & - & - & - & - & - \\
\hline 1996 & 16.795 & 5.719 & 2.957 & 4.168 & 1.840 & 7.569 & 6.482 & 3.900 & 897 \\
\hline 1997 & 16.174 & 4.959 & 2.563 & 4.867 & 2.511 & 7.571 & 6.231 & 4.084 & 990 \\
\hline 1998 & 16.342 & 5.485 & 2.917 & 4.712 & 2.397 & 8.177 & 6.717 & 4.413 & 901 \\
\hline 1999 & 17.812 & 5.426 & 2.749 & 5.570 & 2.881 & 8.708 & 6.925 & 4.482 & 1.148 \\
\hline 2000 & 18.055 & 5.208 & 2.890 & 6.856 & 3.466 & 9.407 & 7.205 & 5.179 & 1.177 \\
\hline 2001 & 17.186 & 4.767 & 2.576 & 6.781 & 3.359 & 8.946 & 6.833 & 4.927 & 1.008 \\
\hline 2002 & 16.705 & 4.356 & 2.313 & - & - & - & - & - & - \\
\hline 2003 & 17.411 & 4.402 & 2.207 & - & - & - & - & - & - \\
\hline
\end{tabular}

Note: The number of NF and TNF establishments can only be identified for the years 1996-2001.

\section{Entrepreneurship and Job Creation}

In this section, we study the role of entrepreneurial establishments in job creation. The methodology used is explained in Section 3.1. In Section 3.2, we consider the overall job creation and job destruction in the Danish economy. Section 3.3 then analyses the importance of entrepreneurship for gross job creation.

\subsection{Methodology}

We determine job creation and job destruction at the establishment level by applying the method developed by Davis and Haltiwanger (1992) and Davis et al. (1996a). Albæk and Sørensen (1998) have previously analysed job creation and job destruction in the Danish economy, but not the importance of establishment age and entrepreneurial establishments in this process. 
The measures of job creation, $C_{i t}$, and job destruction, $D_{i t}$, at establishment $i$ between year's $t-1$ and $t$ are defined as follows:

$$
\begin{aligned}
& C_{i t}=\max \left(X_{i t}-X_{i t-1}, 0\right) \\
& D_{i t}=\max \left(X_{i t-1}-X_{i t}, 0\right)
\end{aligned}
$$

where $X_{i t}$ is employment at establishment $i$ in year $t$ measured as employment in the last week of November. The variable $C_{i t}$ is thus equal to the increase in the number of employees if an increase has occurred. If the number of employees has decreased, the variable is set to zero. Similarly, $D_{i t}$ equals the number of jobs lost if employment has decreased, and equals zero if employment has increased. Note that new establishments have $X_{i t-1}=0$ by construction. Similarly, exiting establishments have $X_{i t}=0$.

We also construct measures of the persistence of jobs created (and destructed). The $k$-year persistence measure of jobs created at establishment $i$ between year $t-1$ and $t$ is constructed as follows (see also Davis and Haltiwanger, 1992):

$$
P_{k i t}^{C}= \begin{cases}\operatorname{Max}\left(X_{i t}-X_{i t-1}, 0\right) & \text { if } X_{i t+k} \geq X_{i t} \\ \operatorname{Max}\left(X_{i t+k}-X_{i t-1}, 0\right) & \text { if } X_{i t+k}<X_{i t}\end{cases}
$$

If the number of jobs at establishment $i$ increases or stays constant between years $t$ and $t+k$, there is full persistence of the jobs created between $t-1$ and $t$. On the other hand, the persistence measure equals the number of remaining jobs if the number of jobs decreases from $t$ to $t+k$. Thus, the persistence measure takes a value between 0 and $C_{i t}$. The former is the case when all the jobs created between $t-1$ and $t$ have been destroyed, whereas the latter is the case when the employment level from period $t$ has been maintained or increased. The persistence measure of jobs destructed is constructed in a similar way.

\subsection{Job Creation and Job Destruction}

In this section, we focus on the overall amount of job creation and job destruction in the Danish economy. Table 2 reports aggregate measures of annual job flows in the period 1994-2003. The key message conveyed by the table is that gross job flows are relatively large in magnitude. The amount of jobs created each year is between $12.8 \%$ and $17.0 \%$ of total employment, with job destruction amounting to between $10.9 \%$ and $15.2 \%$ in the period considered. For comparison, Davis et al. (1996a) report that the average job creation and destruction rates in US manufacturing were 9.1\% and $10.2 \%$, respectively, over the period 1973-1988. One explanation for this difference is, of course, that job turnover has increased between the two periods considered. Another explanation is that Danish establishments on average are smaller than US establishments and that therefore more job creation and destruction is registered in Denmark, while some of it nets out at the larger US establishments.

Table 2 also reveals that annual net creation is positive throughout the 1990s; a period of continued expansion in the Danish economy. Following 2001, the Danish economy enters a (light) recession and net creation becomes negative. In the following, we focus on 1999 and 2001 as two years where net job creation was close to zero. Furthermore, 2001 is the last year in which we have information on all the four subsets of new establishments, $c f$., Table 2. 
Table 2: Aggregate Job Flows, 1994-2003

\begin{tabular}{|c|c|c|c|c|c|}
\hline & $\begin{array}{c}\text { Number of } \\
\text { employees } \\
\text { (X) }\end{array}$ & $\begin{array}{c}\text { Job } \\
\text { creation } \\
\text { (C) }\end{array}$ & $\begin{array}{c}\text { Job } \\
\text { destruction } \\
\text { (D) }\end{array}$ & $\begin{array}{c}\text { Net } \\
\text { creation } \\
\text { (C-D) }\end{array}$ & $\begin{array}{c}\text { Job } \\
\text { reallocation } \\
(\mathrm{C}+\mathrm{D})\end{array}$ \\
\hline \multicolumn{6}{|c|}{ Absolute numbers } \\
\hline 1994 & $1,185,129$ & 201,210 & 139,787 & 61,423 & 340,997 \\
\hline 1995 & $1,212,676$ & 175,646 & 148,099 & 27,547 & 323,745 \\
\hline 1996 & $1,224,905$ & 161,263 & 149,034 & 12,229 & 310,297 \\
\hline 1997 & $1,259,877$ & 172,587 & 137,615 & 34,972 & 310,202 \\
\hline 1998 & $1,291,029$ & 171,261 & 140,109 & 31,152 & 311,370 \\
\hline 1999 & $1,297,954$ & 178,020 & 171,095 & 6,925 & 349,115 \\
\hline 2000 & $1,323,496$ & 191,871 & 166,329 & 25,542 & 358,200 \\
\hline 2001 & $1,330,100$ & 191,676 & 185,072 & 6,604 & 376,748 \\
\hline 2002 & $1,301,903$ & 169,767 & 197,964 & $-28,197$ & 367,731 \\
\hline 2003 & $1,272,173$ & 162,655 & 192,385 & $-29,730$ & 355,040 \\
\hline \multicolumn{6}{|c|}{ Share of Employment } \\
\hline 1994 & 100 & 17.0 & 11.8 & 5.2 & 28.8 \\
\hline 1995 & 100 & 14.5 & 12.2 & 2.3 & 26.7 \\
\hline 1996 & 100 & 13.2 & 12.2 & 1.0 & 25.3 \\
\hline 1997 & 100 & 13.7 & 10.9 & 2.8 & 24.6 \\
\hline 1998 & 100 & 13.3 & 10.9 & 2.4 & 24.1 \\
\hline 1999 & 100 & 13.7 & 13.2 & 0.5 & 26.9 \\
\hline 2000 & 100 & 14.5 & 12.6 & 1.9 & 27.1 \\
\hline 2001 & 100 & 14.4 & 13.9 & 0.5 & 28.3 \\
\hline 2002 & 100 & 13.0 & 15.2 & -2.2 & 28.2 \\
\hline 2003 & 100 & 12.8 & 15.1 & -2.3 & 27.9 \\
\hline
\end{tabular}

Note: The number of jobs is measured as establishment level employment in the last week of November. For non-continuing establishments, employment is set to zero in the following year. For new establishments, lagged employment is set to zero.

To consider the importance of establishment age for job creation and destruction, the distributions of gross job creation and gross job destruction across establishment age are shown in Table 3. The figures refer to the years 1999 and 2001.

The first column shows the number of establishments in each age category that are alive in 1999 and 2001, respectively, while the second column shows the number of establishments that closed down during the last year. Thus, around $12 \%$ of all establishments close down between two years. For young establishments, this percentage is much higher. More than one third of the establishments created in 1998 (or 2000) had thus closed down in 1999 (or 2001).

From the fourth column, we can see that the employment share of young establishments is substantial: In both years, more than 20 percent of the total number of jobs is located in 
establishments aged 0-5 years. Moreover, these relatively young establishments create a considerably larger amount of jobs (column 5): Around 55 percent of gross annual job creation can be attributed to establishments younger than 5 years, and more than 31 percent to new establishments. Whether these new establishments are also entrepreneurial cannot be seen from the table. We will return to this issue below.

Table 3: Aggregate Employment and Job Flows by Establishment Age and Continuation Status, 1999 and 2001

\begin{tabular}{|c|c|c|c|c|c|c|c|c|c|c|c|}
\hline \multirow[b]{3}{*}{ Establishment age } & \multicolumn{3}{|c|}{$\begin{array}{c}\text { Number of establishments } \\
(\mathrm{N})\end{array}$} & \multirow{2}{*}{$\begin{array}{c}\text { Empl. } \\
(\mathrm{X})\end{array}$} & \multirow{3}{*}{$\begin{array}{c}\text { Creation } \\
\text { (C) } \\
\text { Startups/ } \\
\text { Continued } \\
\end{array}$} & \multicolumn{3}{|c|}{$\begin{array}{l}\text { Destruction } \\
\text { (D) }\end{array}$} & \multicolumn{3}{|c|}{ Net Creation (C-D) } \\
\hline & $\begin{array}{c}\text { Startups/ } \\
\text { Continued }\end{array}$ & Shutdowns & Total & & & $\begin{array}{c}\text { Startups/ } \\
\text { Continued }\end{array}$ & Shutdowns & Total & $\begin{array}{c}\text { Startups/ } \\
\text { Continued }\end{array}$ & Shutdowns & Total \\
\hline & & & & & & 1999 & & & & & \\
\hline New establishments & 17,812 & 0 & 17,812 & 56,187 & 56,187 & 0 & 0 & 0 & 56,187 & 0 & 56,187 \\
\hline 1 year & 10,382 & 5,960 & 16,342 & 48,982 & 14,693 & 6,497 & 6,671 & 13,168 & 8,196 & $-6,671$ & 1,525 \\
\hline 2 years & 7,674 & 2,529 & 10,203 & 42,359 & 8,054 & 7,157 & 5,322 & 12,479 & 897 & $-5,322$ & $-4,425$ \\
\hline 3 years & 6,328 & 1,468 & 7,796 & 44,900 & 7,441 & 6,092 & 3,205 & 9,297 & 1,349 & $-3,205$ & $-1,856$ \\
\hline 4 years & 5,632 & 945 & 6,577 & 40,944 & 6,334 & 5,347 & 3,917 & 9,264 & 987 & $-3,917$ & $-2,930$ \\
\hline 5 years & 5,132 & 751 & 5,883 & 46,966 & 6,181 & 5,161 & 2,564 & 7,725 & 1,020 & $-2,564$ & $-1,544$ \\
\hline 6 years & 4,300 & 524 & 4,824 & 40,575 & 4,796 & 4,531 & 1,981 & 6,512 & 265 & $-1,981$ & $-1,716$ \\
\hline 7 years & 4,321 & 479 & 4,800 & 44,179 & 4,407 & 6,371 & 1,330 & 7,701 & $-1,964$ & $-1,330$ & $-3,294$ \\
\hline $8+$ years & 60,595 & 3,561 & 64,156 & 932,862 & 69,927 & 84,448 & 20,501 & 104,949 & $-14,521$ & $-20,501$ & $-35,022$ \\
\hline \multirow[t]{2}{*}{ Total } & 122,176 & 16,217 & 138,393 & $1,297,954$ & 178,020 & 125,604 & 45,491 & 171,095 & 52,416 & $-45,491$ & 6,925 \\
\hline & & & & & & 2001 & & & & & \\
\hline New establishments & 17,186 & 0 & 17,186 & 60,697 & 60,697 & 0 & 0 & 0 & 60,697 & 0 & 60,697 \\
\hline 1 year & 11,695 & 6,360 & 18,055 & 63,633 & 18,461 & 11,300 & 8,133 & 19,433 & 7,161 & $-8,133$ & -972 \\
\hline 2 years & 8,685 & 2,492 & 11,177 & 56,241 & 10,909 & 8,542 & 4,645 & 13,187 & 2,367 & $-4,645$ & $-2,278$ \\
\hline 3 years & 6,663 & 1,360 & 8,023 & 44,663 & 6,800 & 6,427 & 3,124 & 9,551 & 373 & $-3,124$ & $-2,751$ \\
\hline 4 years & 5,468 & 906 & 6,374 & 37,675 & 6,412 & 5,646 & 2,451 & 8,097 & 766 & $-2,451$ & $-1,685$ \\
\hline 5 years & 4,735 & 679 & 5,414 & 39,844 & 4,762 & 5,303 & 2,129 & 7,432 & -541 & $-2,129$ & $-2,670$ \\
\hline 6 years & 4,442 & 531 & 4,973 & 37,649 & 4,971 & 5,056 & 1,822 & 6,878 & -85 & $-1,822$ & $-1,907$ \\
\hline 7 years & 4,191 & 421 & 4,612 & 42,045 & 4,801 & 4,599 & 2,036 & 6,635 & 202 & $-2,036$ & $-1,834$ \\
\hline $8+$ years & 61,441 & 3,759 & 65,200 & 947,653 & 73,863 & 91,949 & 21,910 & 113,859 & $-18,086$ & $-21,910$ & $-39,996$ \\
\hline Total & 124,506 & 16,508 & 141,014 & $1,330,100$ & 191,676 & 138,822 & 46,250 & 185,072 & 52,854 & $-46,250$ & 6,604 \\
\hline
\end{tabular}

Note: The number of jobs is measured as establishment level employment in the last week of November. For non-continuing establishments, employment is set to zero in the following year. For new establishments, lagged employment is set to zero.

Turning to job destruction (columns 6 to 8), the lion's share is accounted for by older establishments, i.e., establishments of 8 years or older. However, also the very young establishments contribute to job destruction - both through shutdowns (column 7) and in continuing establishments (column 6). For the youngest establishments, around half of the job destruction is due to establishments closing down, while the share of job destruction due to shutdowns is only around 25 percent for older establishments. By comparing columns 2 and 7, we can also see that young establishments that close down are on average much smaller than older establishments closing down.

If we exclude start-ups, which by construction have no job destruction in their first year, total net job creation (columns 9 to 11) thus becomes negative already after the first year. The only exception is for 1 year old establishments in 1999 which have a slightly positive contribution. For the young establishments, this is entirely due to establishment closures, as continuing establishments remain having a positive contribution. For the older establishments, both continuing and closing establishments contribute negatively to net job creation.

Hence, at the aggregate level, new establishments are responsible for approximately one third of gross job creation each year. Furthermore, it is primarily new establishments that contributed to employment growth in 1999 and 2001, while both young and older establishments, on average, 
contributed negatively to net creation of jobs. However, if we exclude the effects of shut-downs on net job creation, the average net contribution from an establishment remains positive for the first 46 years an establishment is alive.

For comparison, Davis and Haltiwanger (1992) find that establishment openings are responsible for $20 \%$ of gross job creation in US manufacturing sector, while Neumark et al. (2006) find that new establishments are responsible for around $60 \%$ of gross job creation in the US when considering the entire economy.

\subsection{Job Creation by Entrepreneurial Establishments}

From Table 3, we saw that new establishments account for around one third of gross job creation as well as most of the net job creation in the economy. The important question is now: What is the share of job creation in new establishments that can be attributed to entrepreneurial establishments? To determine this, we apply the definitions of the different subsets of new establishments from Section 2, including our preferred measure of entrepreneurial establishments.

Table 4 presents the contributions to job creation of the different subsets of new establishments (as well as combinations of these). We can see that new establishments of new firms (NF establishments) are responsible for approximately half of the job creation by new establishments. However, using the measure of truly new firms (TNF establishments), the share drops to around 15$17 \%$. Newly self-employed, on the other hand, are responsible for around $10-13 \%$ of job creation (NSE establishments). This share increases to $18-24 \%$ if we also include establishments run be individuals who were self-employed without employees the year before (NE establishments)

Using our preferred measure of entrepreneurial establishments - the union of TNF and NSE establishments - entrepreneurial job creation amounts to slightly less than $25 \%$ of the total job creation by new establishments; with the largest contribution coming from the TNF establishments. This number would increase to 30-34\% if we instead of the NSE establishments used the broader measure of job creation by new employers: The NE establishments. We can take this as the most optimistic estimate on the importance of entrepreneurial job creation, but as previously argued many of the NE establishments are unlikely to be truly entrepreneurial.

For comparison, Neumark et al. (2006) find that around 2/3 of the jobs created by new establishments in the US economy are due to new firms. This in turn implies that around $40 \%$ of the total gross job creation is accounted for by the birth of new firms in their study.

From Table 4, it is also evident that jobs per establishment vary relatively much over the four definitions. New establishments in new firms (NF establishments) generate 4.7-4.9 jobs per establishment in the year of establishment, whereas new employers (NE) generate less than 2.5 jobs per new establishment. This should be compared to the number of jobs per new establishment in general, which equals 3.2-3.5. For our measure of entrepreneurial establishments, the figure equals 2.9 .

In sum, using our preferred measure of entrepreneurial establishments (the union of TNF and NSE establishments), we conclude that entrepreneurs are responsible for around $25 \%$ of the job creation by new establishments and hence about $8 \%$ of the total job creation. Using all new establishments of technically new firms (the NF establishments) as the measure of entrepreneurial job creation would, however, exaggerate the importance of entrepreneurs in this process. 
Table 4 : Job Creation in Entrepreneurial Establishments, 1999 and 2001

\begin{tabular}{|c|c|c|c|c|c|c|}
\hline & \multicolumn{3}{|c|}{1999} & \multicolumn{3}{|c|}{2001} \\
\hline & $\begin{array}{c}\text { Number of } \\
\text { establishments } \\
\text { (N) }\end{array}$ & $\begin{array}{c}\text { Job } \\
\text { creation } \\
\text { (C) }\end{array}$ & $\begin{array}{c}\text { Jobs per } \\
\text { establishment }\end{array}$ & $\begin{array}{c}\text { Number of } \\
\text { establishments } \\
\text { (N) }\end{array}$ & $\begin{array}{c}\text { Job } \\
\text { creation } \\
\text { (C) }\end{array}$ & $\begin{array}{c}\text { Jobs per } \\
\text { establishment }\end{array}$ \\
\hline & \multicolumn{6}{|c|}{ Absolute numbers } \\
\hline All new establishments & 17.812 & 56.187 & 3,2 & 17.186 & 60.697 & 3,5 \\
\hline NE establishments & 5.426 & 13.630 & 2,5 & 4.767 & 10.758 & 2,3 \\
\hline NSE establishments & 2.749 & 7.503 & 2,7 & 2.576 & 6.364 & 2,5 \\
\hline NF establishments & 5.570 & 27.570 & 4,9 & 6.781 & 31.887 & 4,7 \\
\hline TNF establishments & 2.881 & 8.759 & 3,0 & 3.359 & 10.388 & 3,1 \\
\hline NF $\cup$ NE establishments & 8.708 & 34.492 & 4,0 & 8.946 & 35.715 & 4,0 \\
\hline TNF $\cup$ NE establishments & 6.925 & 18.878 & 2,7 & 6.833 & 18.060 & 2,6 \\
\hline TNF $\cup$ NSE establishments & 4.482 & 13.202 & 2,9 & 4.927 & 14.279 & 2,9 \\
\hline \multirow[t]{2}{*}{ TNF $\cap$ NSE establishments } & 1.148 & 3.060 & 2,7 & 1.008 & 2.473 & 2,5 \\
\hline & \multicolumn{6}{|c|}{ Share of total } \\
\hline All new establishments & 100,0 & 100,0 & & 100,0 & 100,0 & \\
\hline NE establishments & 30,5 & 24,3 & & 27,7 & 17,7 & \\
\hline NSE establishments & 15,4 & 13,4 & & 15,0 & 10,5 & \\
\hline NF establishments & 31,3 & 49,1 & & 39,5 & 52,5 & \\
\hline TNF establishments & 16,2 & 15,6 & & 19,5 & 17,1 & \\
\hline NF $\cup$ NE establishments & 48,9 & 61,4 & & 52,1 & 58,8 & \\
\hline TNF $\cup N E$ establishments & 38,9 & 33,6 & & 39,8 & 29,8 & \\
\hline TNF $\cup$ NSE establishments & 25,2 & 23,5 & & 28,7 & 23,5 & \\
\hline TNF $\cap$ NSE establishments & 6,4 & 5,4 & & 5,9 & 4,1 & \\
\hline
\end{tabular}

Note: The number of jobs is measured as establishment level employment in the last week of November.

Table 4 only gives the contribution of new establishments to job creation in their entry year. Another aspect relevant for the understanding of job creation by entrepreneurial establishments is how persistent these jobs are. Are they destructed more or less quickly than jobs created at nonentrepreneurial new establishments and older establishments? On the one hand, it is expected that successful entrepreneurial establishments grow faster, which reduces the risk that jobs created in the first year are eliminated in the next couple of years. On the other hand, entrepreneurial establishments may be much more vulnerable to failure than other new and older establishments.

Note that in the following, we focus on the employment effects within new and entrepreneurial establishments and the corresponding firms. Another approach used in the literature is to look at the effect on the overall employment level from entrepreneurship. This has been investigated by Stel and Suddle (2008), Fritsch and Mueller (2008), and Mueller, Stel and Storey (2008), who all focus on the overall intertemporal employment effects from start-ups in a country or a region.

The upper part of Table 5 displays persistence measures of the jobs created and the jobs destructed in 1999 by new and older establishments, calculated according to (2). We track the effects over the subsequent four years until 2003, which is the last year of our data set. There are several things to note from the table. First, the persistence of jobs created at new establishments is generally higher than the persistence of jobs created at older establishments. 
Table 5: Persistence Measures and Employment in the Years Following Entry, 1999

\begin{tabular}{|c|c|c|c|c|c|c|c|c|c|c|}
\hline & \multirow{2}{*}{$\begin{array}{l}\text { Job } \\
\text { creation } \\
\text { (C) }\end{array}$} & \multirow{2}{*}{$\begin{array}{c}\text { Job } \\
\text { destruct. } \\
\text { (D) }\end{array}$} & \multicolumn{2}{|c|}{ One-Year persistence } & \multicolumn{2}{|c|}{ Two-year persistence } & \multicolumn{2}{|c|}{ Three-year persistence } & \multicolumn{2}{|c|}{ Four-year persistence } \\
\hline & & & $\begin{array}{c}\text { Creation } \\
\left(\mathrm{P}_{1}^{\mathrm{C}}\right)\end{array}$ & $\begin{array}{c}\text { Destruct. } \\
\left(\mathrm{P}_{1}^{\mathrm{D}}\right)\end{array}$ & $\begin{array}{c}\text { Creation } \\
\left(\mathrm{P}_{2}^{\mathrm{C}}\right)\end{array}$ & $\begin{array}{c}\text { Destruct. } \\
\left(\mathrm{P}_{2}^{\mathrm{D}}\right)\end{array}$ & $\begin{array}{c}\text { Creation } \\
\left(\mathrm{P}_{3}{ }^{\mathrm{C}}\right)\end{array}$ & $\begin{array}{c}\text { Destruct. } \\
\left(\mathrm{P}_{3}{ }^{\mathrm{D}}\right)\end{array}$ & $\begin{array}{c}\text { Creation } \\
\left(\mathrm{P}_{4}{ }^{\mathrm{C}}\right)\end{array}$ & $\begin{array}{c}\text { Destruct. } \\
\left(\mathrm{P}_{4}{ }^{\mathrm{D}}\right)\end{array}$ \\
\hline Establishment age & \multicolumn{2}{|c|}{ Absolute numbers } & \multicolumn{8}{|c|}{ Share of intial job-creation (destruction) } \\
\hline All new establishments & 56.187 & - & 73 & - & 60 & - & 51 & - & 44 & - \\
\hline 1 year & 14.693 & 13.168 & 69 & 91 & 53 & 89 & 42 & 88 & 34 & 87 \\
\hline 2 years & 8.054 & 12.479 & 64 & 90 & 49 & 87 & 40 & 86 & 34 & 85 \\
\hline 3 years & 7.441 & 6.512 & 60 & 87 & 47 & 82 & 38 & 80 & 32 & 79 \\
\hline 4 years & 6.334 & 7.701 & 61 & 84 & 45 & 72 & 37 & 66 & 30 & 63 \\
\hline 5 years & 6.181 & 5.998 & 53 & 84 & 42 & 76 & 31 & 73 & 25 & 72 \\
\hline 6 years & 4.796 & 5.700 & 61 & 84 & 41 & 77 & 31 & 75 & 27 & 73 \\
\hline 7 years & 4.407 & 4.637 & 59 & 86 & 44 & 78 & 37 & 76 & 30 & 74 \\
\hline 8 years & 4.237 & 5.623 & 66 & 79 & 50 & 73 & 40 & 71 & 31 & 69 \\
\hline 9 years & 4.007 & 3.738 & 66 & 81 & 50 & 74 & 35 & 68 & 27 & 67 \\
\hline 10 years & 4.036 & 3.990 & 66 & 81 & 46 & 75 & 32 & 71 & 26 & 70 \\
\hline $11+$ years & 57.647 & 69.461 & 65 & 83 & 49 & 76 & 38 & 73 & 31 & 71 \\
\hline Total & 178.020 & 171.095 & 67 & 85 & 52 & 78 & 42 & 76 & 35 & 74 \\
\hline All new establishments & 56.187 & - & 73 & - & 60 & - & 51 & - & 44 & - \\
\hline NE establishments & 13.630 & - & 67 & - & 52 & - & 41 & - & 35 & - \\
\hline NSE establishments & 7.503 & - & 69 & - & 53 & - & 43 & - & 37 & - \\
\hline NF establishments & 27570 & - & 75 & - & 63 & - & 54 & - & 47 & - \\
\hline TNF establishments & 8.759 & - & 73 & - & 57 & - & 45 & - & 39 & - \\
\hline NF $\cup$ NE establishments & 34.492 & - & 73 & - & 60 & - & 51 & - & 44 & - \\
\hline TNF $\cup N E$ establishments & 18.878 & - & 69 & - & 54 & - & 43 & - & 37 & - \\
\hline TNF $\cup$ NSE establishments & 13.202 & - & 71 & - & 55 & - & 44 & - & 38 & - \\
\hline TNFคNSE establishments & 3.060 & - & 70 & - & 53 & - & 43 & - & 36 & - \\
\hline
\end{tabular}

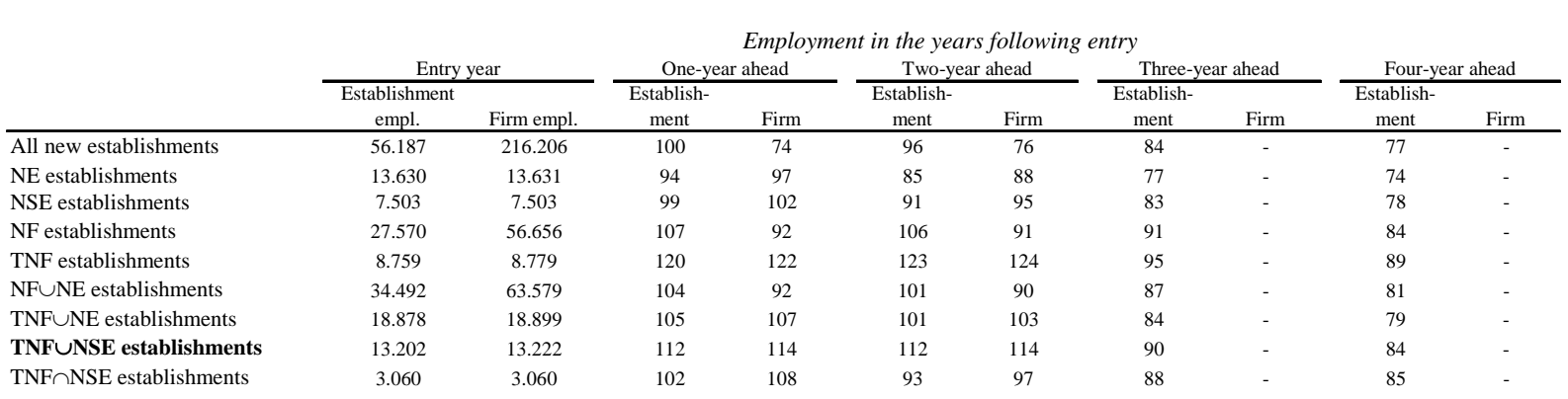

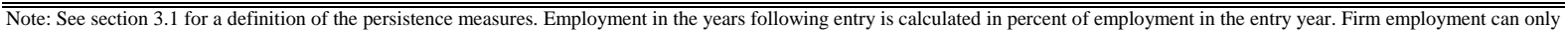
be tracked until 2001.

Second, among the different subsets of new establishments, persistence is highest on NF and TNF establishments which have persistence rates that correspond to those for new establishments in general. Persistence rates of jobs created by new self-employed (NSE establishments) and new employers (NE establishments) are somewhat lower. For our preferred measure of entrepreneurial establishments the persistence measure thus becomes slightly lower than for new establishments in general

Persistence measures of job destruction are generally somewhat higher. However, this is to be expected since some of the destructed jobs reflect establishment exits where the jobs by definition remain destructed. Furthermore, the persistence rates of job destruction are slightly higher for younger establishments. This reflects that these have a higher risk of exiting.

The persistence measures only capture what happens to the jobs that were created in the first year not the amount of additional jobs created in the following years. To throw some light on this latter 
aspect, the lower part of Table 5 presents total employment within the new establishments in the years following entry, as well as the total employment within the firm (the legal unit), i.e., including employment at other establishments in the same firm.

First, note that for the set of all new establishments, total firm employment is four times higher than establishment employment in the initial year, reflecting that many of the new establishments are established by existing firms. Second, firm employment also significantly exceeds establishment employment for the NF establishments (by a factor 2), which reflects that these firms also have older establishments, which have been acquired from other firms. This is a strong indication that many of the NF establishments are not establishments of truly new firms. Instead, the (technically) new firm is likely to be a result of changes in the legal structure of existing firms. This result thus confirms that using NF establishments as a measure of entrepreneurial establishments would be inappropriate.

Third, while new establishments are on average 23 percent smaller in terms of jobs after 4 years, TNF establishments are only 11 percent smaller. After two years, these establishments are in fact considerably bigger (23 percent) than in their start-up year. A similar, although less strong, picture applies to our preferred measure of entrepreneurial establishments (the union of TNF and NSE establishments), which are 16 percent smaller after four years but 12 percent larger after two years. This points to a somewhat better performance of entrepreneurial establishments than other new establishments in generating jobs in the years following their entry - a performance which is driven in particular by the TNF establishments. Quantitatively, however, this may add at most a few percentage points to the results for job creation by entrepreneurial establishments from Table $4 .^{6}$

Fourth, establishments of new self-employed (NSE establishments) and establishments of new employers (NE establishments) have in themselves a poorer performance in this respect. Four years after entry, they retain only around $75 \%$ of the jobs from the entry year. This corresponds to the performance of all new establishments in general.

\section{Entrepreneurship and Average Wages}

Creative destruction may not only impact on jobs by replacing old jobs at exiting establishments with new jobs at entering establishments. Schumpeter's hypothesis was that it would also create more productive jobs. Thus, the process of creative destruction may also be expected to affect the average wage level in the economy. If the old jobs that disappear earn a lower wage than the new ones that enter, this will raise the average wage level in the economy.

In this section, we analyse the importance of entrepreneurship for average wage increases in the Danish economy using a decomposition technique suggested by Foster et al. (2001) and used by Bartelsman et al. (2004). This method decomposes the average wage increase into parts that can be ascribed to continuing, exiting and entering establishments, respectively. The decomposition is presented in Section 4.1, while the results of the decomposition are presented in Section 4.2.

\footnotetext{
${ }^{6}$ For example, adding 23\% to job creation by TNF establishments in 1999 while reducing job creation by new establishments by four percent (as suggested by the two-year ahead measures in the lower part of Table 5) can raise the share of TNF establishments in job creation by new establishments from the $15.6 \%$ reported in Table 4 to $20 \%$. This in turn could raise their share in total job creation by 1-2 percentage points.
} 


\subsection{Decomposition Technique}

We adapt a slightly modified version of the decomposition technique from Foster et al. (2001). Formally, define $W_{t}$ as the average wage in year $t$ :

$$
W_{t}=\sum_{i=1}^{n_{t}} \theta_{i t} w_{i t}
$$

where $w_{i t}$ is the wage rate at establishment $i$ in year $t$, and $\theta_{i t}$ is the share of establishment $i$ in total employment in year $t$. Now, the change in $W_{t}$ between two years $(t-k$ and $t)$ can be decomposed as follows:

$$
\begin{aligned}
\Delta W_{t-k}=\sum_{i \in C} \bar{\theta}_{i} \Delta w_{i t}+\sum_{i \in C} \Delta \theta_{i t}\left(\bar{w}_{i}-\bar{W}\right) \\
\quad+\sum_{i \in N} \theta_{i t}\left(w_{i t}-W_{t-k}\right)-\sum_{i \in X} \theta_{i t-k}\left(w_{i t-k}-W_{t-k}\right)
\end{aligned}
$$

where $C$ is the set of continuing establishments, i.e., establishments alive in both $t-k$ and $t, N$ is the set of entering establishments, i.e., establishments alive only in the last year, $t$, and $X$ is the set of exiting establishments, i.e., establishments alive only in the first year, $t-k$. A bar above a variable indicates the average value over years $t$ and $t-k, e . g ., \bar{w}_{i}=\left(w_{i t}+w_{i t-k}\right) / 2$.

The first two terms on the right hand side in (4) represent the part of the wage change which is due to continuing establishments. The first term is the so-called "within-establishment effect". It is the contribution to the growth in average wages from continuing establishments increasing their wages. It is calculated as the changes in wages of continuing establishments, $\Delta w_{i t}=w_{i t}-w_{i t-k}$, weighted by their average shares in the economy $\bar{\theta}_{i}$. The second term is the "between-establishment effect", which gives the increase in average wages that stems from continuing establishments expanding or contracting their share in employment. It is calculated as the change in the market share of establishment $i$ times the difference between this establishment's average wage and the economywide average wage. Thus, if establishments that pay higher wages than the average expand, then the average wage goes up. As our interest is in the effect of entering (and exiting) establishments, we shall only report the sum of these two terms in what follows.

The third term is the "entry effect". It gives the contribution by entering establishments and is calculated as the share of each entering establishment times the difference between this establishment's wage rate and the economy's wage rate. So, if entering establishments pay higher wages than existing establishments, they have a positive contribution to average wage growth. It is this term which has our main interest.

The fourth term is the "exit effect", which gives the contribution by exiting establishments to wage changes. It is calculated as the initial share of the exiting establishment times the gap in wages between this establishment and the economy average. If the establishment pays lower wages than the average, its exit contributes to a higher average wage rate in the economy.

Finally, we use our different subsets of new establishments to analyse the importance of these for the "entry effect". Specifically, are entrepreneurial establishments responsible for a particularly large share of the entry effect? 


\subsection{Results}

We measure the average wage at establishment $i$ in year $t$ as the wage bill in year $t$ divided by the number of employees in year $t^{7}$ This average wage is then deflated by the consumer price index. Table 6 reports the results from a decomposition of changes in the average wage for the private sector over 3-year periods. Thus, the first column gives the increase in the average wage (measured in 2002 prices) between 1996 and 1999.

Table 6: Decomposition of the Increase in Average Wages, 1996-2003

\begin{tabular}{|c|c|c|c|c|c|}
\hline & 1999 & 2000 & 2001 & 2002 & 2003 \\
\hline \multirow[t]{2}{*}{ Wage Increase in DKK (from $t-3$ to $t$ ) } & 10.611 & 10.553 & 8.895 & 6.943 & 6.097 \\
\hline & \multicolumn{5}{|c|}{ Shares of total wage increase between $t-3$ and $t$} \\
\hline Within and between effects & 89 & 84 & 81 & 88 & 78 \\
\hline Exit effect & 17 & 11 & 7 & 18 & 33 \\
\hline Entry effect & -6 & 5 & 12 & -6 & -11 \\
\hline \multicolumn{6}{|l|}{ Entry effect by: } \\
\hline NE establishments & $-13,0$ & $-14,6$ & $-18,3$ & $-23,4$ & $-28,8$ \\
\hline NSE establishments & $-6,8$ & $-7,9$ & $-10,4$ & $-13,5$ & $-15,8$ \\
\hline NF establishments & 1,9 & 9,7 & 18,9 & & \\
\hline TNF establishments & $-2,6$ & $-1,2$ & 0,4 & & \\
\hline NF $\cup$ NE establishments & $-2,5$ & 6,1 & 15,8 & & \\
\hline TNF $\cup$ NE establishments & $-10,2$ & $-9,4$ & $-9,7$ & & \\
\hline TNF $\cup N S E$ establishments & $-5,2$ & $-4,1$ & $-3,3$ & & \\
\hline TNF $\cap$ NSE establishments & $-2,6$ & $-3,1$ & $-4,6$ & & \\
\hline
\end{tabular}

Note: Wages are measured in 2002 prices. The aggregate consumption price index was used as price deflator. Average wages are weighted by plant size (number of employees).

It shows very clearly that most (80-90\%) of the observed increases can be ascribed to within and between establishment wage increases. Moreover, establishment exits have systematically positive contributions, suggesting that exiting establishments are low-wage establishments. The results for entering establishments are more mixed, being positive in some years and negative in other years. In general, however, the effect does not seem to be "significantly" different from zero.

Turning to the entrepreneurial establishments, we observe that the union of TNF and NSE establishments contribute slightly negatively to the increase in average wages. This limited effect is especially driven by a negative contribution from NSE establishments.

Based on this, we may conclude that Schumpeter was at least partly right in the case of Denmark: Old and less productive firms are replaced by new and more productive firms - although not more productive than existing firms; at least not in the first couple of years.

Moreover, it is evident that establishments owned by new employers (NE establishments) have particularly negative contributions to average wage growth, while the contribution of new

\footnotetext{
${ }^{7}$ In this section, employment is measured as the number of fulltime equivalent workers.
} 
establishments in new firms (NF establishments) seems to be positive on average. As the NE and NSE establishments also accounted for much less job creation than establishments owned by new firms, these must be very low-wage establishments. This is confirmed by results not displayed, which show that average wage rates in NE and NSE establishments are only around 3/4 of wage rates in NF and TNF establishments. Thus, new self-employed do not create high-wage jobs.

An obvious limitation of the above decomposition is, of course, that we do not control for worker characteristics in computing the average wages. Thus, it might actually be the case that entrepreneurial establishments contribute to average wage growth if they hire, e.g., less educated (or less experienced) workers than other establishments. In that case, a zero contribution to the average wage translates into a positive contribution to the education-specific wage.

\section{Conclusion}

The purpose of this paper was to analyse the importance of entrepreneurs for job creation and average wage growth. To do this, we applied a unique dataset for the Danish economy that allowed us to define four different subsets of new establishments and combinations thereof. The measures allowed us not only to provide a better picture of the role of entrepreneurial establishments than previous studies relying mostly on information about small firms, but also to compare the importance of the "firm-birth" and the "self-employment" approach to entrepreneurship.

First, we argued that the union of the new establishments of truly new firms (the TNF establishments) and the establishments of new self-employed (the NSE establishments) was our preferred measure of entrepreneurial establishments. However, the establishments of new selfemployed (NSE establishments) and even the establishments of new employers (NE establishments) were also interesting in their own right, as much of the entrepreneurship literature has focussed on the self-employed.

Second, we found that while new establishments in general are responsible for around 1/3 of total gross job creation, the entrepreneurial establishments account for around $25 \%$ of this, and hence about $8 \%$ of the total gross job creation. The new self-employed in themselves, however, account for only $10-13 \%$ of the gross job creation by new establishments. Extending the measure of new self-employed to include also those who were previously self-employed without employees increases this share to between $17 \%$ and $24 \%$.

Third, we also argued that using new firms as the measure of entrepreneurs is likely to exaggerate the importance of entrepreneurial activity considerably. While new establishments of formally new firms account for around half of the job creation by new establishments, many of these firms are unlikely to be truly entrepreneurial firms, but instead the result of changes in the legal set-up of a firm. This is most clearly illustrated by the fact that the new establishments in these "new" firms account only for around half of the total employment in these firms, indicating the presence of a number of older establishments as well.

Fourth, even though jobs created by entrepreneurial establishments do not exhibit higher persistence than jobs created by other new establishments, we find some evidence that entrepreneurial establishments create more additional jobs in the years following entry than other new establishments. Quantitatively, this may raise the contribution of entrepreneurs in total job creation 
by 1-2 percentage points. Furthermore, this performance was in particular driven by the establishments of truly new firms, while the new establishments of self-employed displayed a somewhat poorer performance in this respect.

Fifth, we also decomposed the change in the average wage level to analyse the importance of entrepreneurs for wage growth. While the exit of low-wage establishments adds considerably to the growth in average wages, the evidence for entering establishments is more mixed. Establishments of new self-employed and new employers have a clear negative effect on the average wage level, revealing that these create mostly low-wage jobs. However, the TNF establishments did not seem to decrease (or increase) the average wage level, thereby limiting the total negative effect of entrepreneurial establishments.

In sum, while entrepreneurship may be responsible for around $25 \%$ of job creation by new establishments and around $8 \%$ of overall job creation, entrepreneurship does not seem to be responsible for changes in the average wage level - at least not in the short run.

\section{References}

Albæk, K. and B. Sørensen (1998): "Worker Flows and Job Flows in Danish Manufacturing, 198091" Economic Journal, 108, 1750-1771.

Audretsch, D.B. and M. Fritsch (2002): "Growth Regimes over Time and Space", Regional Studies, 36, 113-124.

Bartelsman, E., J.C. Haltiwanger, and S. Scarpetta (2004): "Microeconomic Evidence of Creative Destruction in Industrial and Developing Countries", IZA Discussion Paper No. 1374.

Birch, D.L. (1979): The Job Generation Process. The MIT Programme on Neighbourhood and Regional Change, Cambridge, MA.

Birch, D.L. (1987): Job Creation in America: How Our Smallest Companies Put the Most People to Work. Free Press, New York.

Brixy, U., S. Kohaut, and C. Schnabel (2007): "Do Newly Founded Firms Pay Lower Wages? First Evidence from Germany", Small Business Economics, 29, 161-171

Brown, C., and J.L. Medoff (2003): "Firm Age and Wages", Journal of Labor Economics, 21, 677697.

Davis, S.J. and J.C. Haltiwanger (1992): "Gross Job Creation, Gross Job Destruction and Employment Reallocation", Quarterly Journal of Economics, 107, 819-863.

Davis, S.J., J.C. Haltiwanger and S. Schuh (1996a): Job Creation and Destruction. MIT Press, Cambridge.

Davis, S.J., J.C. Haltiwanger and S. Schuh (1996b): "Small Business and Job Creation: Dissecting the Myth and Reassessing the Facts", Small Business Economics, 8, 297-315.

Dunne, T., M. Roberts, and L. Samuelson (1989): "The Growth and Failures of U.S. Manufacturing Establishments", Quarterly Journal of Economics, 104, 671-698.

Fritsch, M. and P. Mueller (2008), "The Effect of New Business Formation on Regional Development over Time: The Case of Germany," Small Business Economics, 30(1), 15-29.

Foster, L.S., J.C. Haltiwanger, and C.J. Krizan (2001): "Aggregate Productivity Growth: Lessons from Microeconomic Evidence", in E. Dean, M. Harper and C. Hulten (eds.): New Developments in Productivity Analysis. Chicago: University of Chicago Press.

Iversen, J., R. Jørgensen, and N. Malchow-Møller (2008): "Defining and Measuring Entrepreneurship", Foundations and Trends in Entrepreneurship, 4, 1-63. 
Klette, T.J. and A. Mathiassen (1996): "Job Creation, Job Destruction and Establishment Turnover in Norwegian Manufacturing", Annales d'Économie et de Statistique, 41/42, 97-125.

Mueller, P., A. van Stel and D. J. Storey, (2008), "The Effects of New Firm Formation over Time: The Case of Great Britain," Small Business Economics, 30(1), 59-71.

Neumark, D., J. Zhang, and B. Wall (2006): "Where the Jobs are: Business Dynamics and Employment Growth", Academy of Management Perspectives, 20, 79-94.

Neumark, D., B. Wall, and J. Zhang (2008): "Do Small Businesses Create More Jobs? New Evidence from the National Establishment Time Series", NBER working paper no. 13818.

Oi, W.Y., and T. Idson (1999): "Firm Size and Wages", in O. Ashenfelter and D. Card (eds.): Handbook of Labor Economics, Vol. 3, Elsevier Science, Amsterdam, 2165-2214.

Parker, S.C. (2004): The Economics of Self-Employment and Entrepreneurship. Cambridge University Press, Cambridge.

Spletzer, J. (2000): "The Contribution of Establishment Births and Deaths to Employment Growth", Journal of Business and Economic Statistics, 18, 113-126.

Statistics Denmark (2002): Tilgang af Nye Virksomheder. Danmarks Statistik, København.

Storey, D.J. (1991): "The Birth of New Firms - Does Unemployment Matter? A Review of the Evidence", Small Business Economics, 3, 176-178.

van Stel, A.J. and D.J. Storey (2004): "The Link between Firm Births and Job Creation: Is there a Upas Tree Effect?", Regional Studies, 38, 893-909.

van Stel, A. and K. Suddle, 2008, "The Impact of New Firm Formation on Regional Development in the Netherlands", Small Business Economics, 30(1), 31-47. 